\title{
AN INVESTIGATION OF THE RELATIONSHIP BETWEEN SCHOOL SATISFACTION DURING THE TIME ORIENTATION CLASSROOM DISENGAGEMENT AND PERCEIVED CONTROL
}

\author{
Gülfem Meylan ŞAHİNBAŞ ${ }^{1}$ \\ Ali ERYILMAZ ${ }^{2}$ \\ Özkan SAPSAĞLAM ${ }^{3}$
}

\begin{abstract}
${ }^{1}$ Teacher, Ministry of National Education, meylansahinbasgmail(at)gmail.com, ORCID: 0000-0002-9817-453X
${ }^{2}$ Professor, Yildiz Technical University, erali76(at)hotmail.com, ORCID: 0000-0001-9301-5946

${ }^{3}$ Assoc. Professor, Yildiz Technical University, ozkaanim(at)gmail.com, ORCID: 0000-0002-9965-5191
\end{abstract}

Şahinbaş, Gülfem-Meylan, Eryılmaz Ali \& Sapsağlam, Özkan. "An Investigation of the Relationship between School Satisfaction during the Time Orientation Classroom Disengagement and Perceived Control”. ulakbilge, 44 (January 2020): s. 17-25. doi: 10.7816/ulakbilge-08-44-02

\begin{abstract}
School satisfaction is the state in which a student enjoys the educational process and the time he/she spends at school. High level of school satisfaction positively affects students' academic achievement and self-image and contributes to their social development. Some other individual characteristics such as attending to lessons, attention, recall and perceived control affect learning outcomes and academic achievement. This study was conducted with 3rd and 4th grade students at primary school level 253 students from private and public primary schools participated in the study. Personal Information Form, Overall School Satisfaction Scale for Children, Time Orientation during Classroom Disengagement Scale for primary school children, and General Perceived Control Scale for primary school children were used as data collection tools. Quantitative data analysis methods were used in the research which is based on quantitative research approach and correlational survey design. In the data analysis process, t test and multiple regression analysis were used. There was no difference in school satisfaction of students based on gender and grade level. Results revealed that total time orientation during classroom disengagement, the first variable that was investigated in terms of its effect on school satisfaction, explained the students' school satisfaction in a significant and negative way.
\end{abstract}

Keywords: Perceived control, school satisfaction, classroom disengagement, time orientation 


\section{Introduction}

School satisfaction is one of the important areas reflecting the well-being of individuals. Well-being is defined as an individual's evaluation of his or her own life. This evaluation is both cognitive and emotional (Diener and Diener, 1996). Life satisfaction, which is a cognitive dimension of well-being, is the cognitive assessment of a person's whole life or specific area (family, environment, etc.) in terms of its quality or positivity (Haranin, Huebner ve Suldo, 2007). School satisfaction, which is the sub-dimension of life satisfaction, is an element of both well-being and general life satisfaction (Casas, Bello, González and Aligué, 2013). Students who get satisfaction from the school are interested in school and behave in a way that will improve their perceived positive abilities and academic achievement. Students who are dissatisfied with school may exhibit more internalized and externalized behaviors in order to avoid or escape school life. Socially withdrawn students may perceive school life negatively and deliberately leave the school (King, Huebner, Suldo and Valois, 2006). Students' indifference and reluctance to lessons, exhibition of various behavioral disorders in classrooms and their unwillingness to come to school may affect their whole life. When the studies related to students' non-attendance to lessons are examined, it was investigated that many of the students get bored, they cannot focus their attention on the topic, and they cannot make a connection between what is done at school and real life when they are not motivated to participate in lessons (Barton, 2004). According to Fredricks, Blumenfeld and Paris (2004), students' display of absenteeism, negative behaviors and low level of effort for the lessons can be considered as the behavioral indicators of school absenteeism. Students' unwillingness to complete the compulsory education, their escapes from the school and absenteeism are examples of non-attendance to school (Morris and Pullen, 2007; Martin, 2001, 2002, 2003). Time orientation is one of the factors that affect student's school satisfaction.

Zimbardo and Boyd (1999) developed the Time Perspective Theory using Levin's views. According to the theory, time orientation is defined as the unconscious process that develops as the individual's personal and social experiences continue unceasingly. This process supports the classification and interpretation of experiences and affects the current processes of judgement and making decisions and behaviors (Zimbardo and Boyd, 1999). While individuals with a predominant past orientation use their true life experiences as base in their decisions, individuals with predominant future orientations make decisions based on their benefit-loss expectations in the future. In both cases, abstract cognitive processes are important (Zimbardo and Boyd, 2008). The more active use of one of these cognitive processes in the decision-making process, together with a transient cognitive bias, which leads to past, future or present orientation, affects the person's daily life and personality when this situation chronically appears. Balanced time perspective is an appropriate state of functionality and being healthy (Zimbardo and Boyd, 1999). In addition, students' time orientation in the situations of not attending lessons is also an important issue. At this point, it is investigated that when students are in class disengagement, primary school students lose control in experiencing the pleasure and pain of the past, behaving in the present, and satisfying their future needs (Eryılmaz and Dereli, 2011). For a person to be aware of his/her competence, he/she has to use all time orientations in the most appropriate way and his/her perceived control skills have to be sufficient.

Perceived control is defined such beliefs as individual might produce desired consequences (Skinner, 1995). According to Skinner, there are four important theories of perceived control (Skinner, 1996). To her, perceived control needs to be explained along with the locus of control, learned helplessness and self-efficacy theories that form the basis of this concept. The locus of control is particularly relevant to expectations. A person's successful experience in behavior is decisive in his / her next behavior and leads to expectation, similarly his / her unsuccessful experience decreases his/her expectations in terms of being successful (Lefcourt, 1982). Learned helplessness consists of three elements: discontinuity, cognition and behavior. Discontinuity draws attention to the concrete relationships between one's actions and the consequences of those actions. Cognition is the act of a person's interpretation of his/her perceived discontinuity. Behavior is related to the observable consequences of discontinuity and the person's cognition. The learned helplessness theory puts emphasis on how active and passive a person is when he/she is faced with a situation that he/she cannot control. It is revealed that one does not perform cognitively when he/she feels helpless about the future and changes appear in his/her immune system with the low self-respect (Peterson, Maier, Seligman, 1993).

When the literature related to the research topic is reviewed, following studies were found: The adap tation of comprehensive school satisfaction scale for children to Turkish (Telef, 2014), examination of the school 
satisfaction levels of Romany children in terms of various variables (Öksüz, Demir and Öztürk, 2018), investigation of primary school students' level of responsibility in terms of school attachment and satisfaction (Kaplanc1, 2018), the development of a measurement tool that measures the time orientations of primary school students during classroom disengagement (Eryılmaz and Dereli, 2011), the mediator role of relationship satisfaction on the relation between time perspective and responses to relationship problems (Yaşın and Büyükşahin, 2016), the development of perceived control scale for primary school students (Dereli-Iman and Eryilmaz, 2012), and examining the relationship between subjective well-being and perceived control (Eryilmaz and Ercan, 2011).

School satisfaction has many positive results. For example, it has been found that students' academic achievement increases (Okun, Braver and Weir, 1990) and school stress decreases (Karatzias, Powe, Flemming, 2002). In addition, as school satisfaction increased, students' well-being levels (Katja, Marja-Terttu and Pekka, 2009) and their adaptation to school were found to increase (Baker and Maupin, 2009). However, no study has been found to investigate the relationship between school satisfaction and time orientation during classroom disengagement and perceived control of children. In conclusion, this study aimed to investigate the relationship between school satisfaction and time orientation during classroom disengagement and perceived control of children.

\section{Methodology}

\section{Research Goal}

The aim of this study is to investigate the relationship between school satisfaction, time orientation during classroom disengagement, perceived control, and demographic variables. In this study, answers to the following questions are sought with the belief that they will reveal the structure of the relations:

1. Do the time orientation during classroom disengagement and perceived control predict school satisfaction in children?

2. Is there a difference in terms of school satisfaction based on gender and grade level?

\section{Research Design}

The study is based on quantitative research methods. In this respect, the study was conducted according to relational screening model. Relational screening aims to determine the existence of change or the level of change between two and more variables (Karasar, 2000).

\section{Sample and Data Collection}

The population of the study consisted of primary school students and the sample involved 253 primary school students studying in one private and one public primary school. Simple random sampling method was used to determine the sample group. While 124 of the students are in the 3rd grade and 129 of them are in the 4th grade. 29 students $(11.5 \%)$ are 8,104 students $(41.1 \%)$ are 9,115 students $(45.5 \%)$ are 10 and 5 students $(5 \%)$ are 11 years old.

Various data collection tools were used in collecting the data. First of all, a personal information form including the demographic information of the students was created and some of the data were collected with this information form. The rest of the data were collected through the school satisfaction scale, the time-orientation during classroom disengagement scale for primary school students and the perceived control scale for children.

Overall School Satisfaction Scale for Children: The school satisfaction scale adapted by Telef (2014) consists of 6 items in total, and it has one dimension. The internal consistency coefficient for the whole scale was .89.

Time Orientation During Classroom Disengagement Scale for primary school children: This scale was developed by Eryılmaz and Dereli (2011). It consists of 26 items. The dimensions of the scale were named as "Presenting Behaviors Now", "Thinking Whether or Not to Achieve Development Task in the Future", Thinking Satisfying the Needs in the Future, "Loss of Control", "Thinking of Problems in the Past" and "Thinking of the 
Pleasure in the Past". The internal consistency coefficients of the sub-dimensions were found as 0.79 for Presenting Behaviors Now, 0.77 for Thinking Whether or Not to Achieve Development Task in the Future, 0.75 for Thinking Satisfying the Needs in the Future, 0.81 Loss of Control, 0.78 for Thinking of Problems in the Past and 0.75 for Thinking of the Pleasure in the Past.

General Perceived Control Scale for primary school children: This scale was also developed by Dereli-İman and Eryllmaz (2012) for primary school children. The scale consists of 5 items in total. The Cronbach Alpha internal consistency coefficient was 0.70 ; and it has no sub-dimensions. According to the results of the analysis, the reliability value of the scale was found to be 0.68 .

\section{Analyzing of Data}

Quantitative data analysis methods were used in the study. In this respect, t-test technique was used for independent groups in order to examine whether school satisfaction makes a significant difference in terms of gender and grade level. Besides, multiple regression analysis was used to determine whether time orientation during classroom disengagement and perceived control level predicted school satisfaction significantly.

\section{Findings}

Descriptive statistics were presented as findings primarily in the study. Then t-test results for independent groups and multiple regression analysis results were provided. The findings are shown in the tables below.

Table 1. Descriptive Statistics

\begin{tabular}{llll} 
& $\mathrm{n}$ & Mean & Ss \\
\hline School Satisfaction & 253 & 25.73 & 4.74 \\
Total Time & 253 & 46.94 & 18.03 \\
Perceived Control & 253 & 16.17 & 2.88 \\
\hline
\end{tabular}

Mean scores and standard deviation values of the variables were given in Table 1. The school satisfaction mean score of all students participating in the study was $25.73(\mathrm{hp}=4.74)$, their mean score in the total time orientation during classroom disengagement was $46.94(\mathrm{hp}=18.03)$, and their mean score in the perceived control scale was 16.17 ( $\mathrm{ss}=2.88)$.

Table 2. Descriptive Statistics and Independent Samples t Test Results

\begin{tabular}{ccccccc} 
Scale Dimensions & Gender & $\mathrm{n}$ & Mean & $\mathrm{t}$ & $\mathrm{Df}$ & $\mathrm{p}$ \\
\hline School Satisfaction & Female & & & & & \\
& & 139 & 26.05 & 1.203 & 250 & .230 \\
& & & & & \\
Male & 114 & 25.33 & & 243 & \\
\hline
\end{tabular}

Independent samples $\mathrm{t}$ test was used to determine whether there is a statistically significant difference on school satisfaction based on gender variable. The results showed that the difference between the mean scores of female students $($ mean $=26.05)$ and those of the males $($ mean $=25.33)$ was not significant $(\mathrm{t}(250)=1.203 ; \mathrm{p}>$ $.05)$. 


\begin{tabular}{lcccccc} 
Scale Dimensions & Grade Level & $\mathrm{n}$ & Mean & $\mathrm{t}$ & Df & $\mathrm{p}$ \\
\hline School Satisfaction & 3rd Grade & 124 & 25.64 &.-284 & 251 & .777 \\
& & & & & & \\
& 4rd Grade & 129 & 25.81 & & 247 & \\
\hline
\end{tabular}

In order to determine whether there is a statistically significant difference on school satisfaction based on grade level, another independent samples $t$ test analysis was implemented. According to the results, there is no significant difference between the mean scores of 3rd grade students (mean $=25,64)$ and those of 4 th graders $($ mean $=25,81)(\mathrm{t}(251)=.-284 ; \mathrm{p}>.05)$.

Table 4. Pearson Correlation Table Showing the Correlation between Variables

\begin{tabular}{llll}
\hline Variables & 1 & 2 & 3 \\
\hline 1. School Satisfaction & 1 & & \\
2. Time Orientation Total Score &.$-284 * *$ & 1 & 1 \\
3. Perceived Control & $.373 * *$ &.$-126^{*}$ & \\
\hline$* p<.05 * * p<.001$ & & &
\end{tabular}

Table 4 shows the results of Pearson correlation analysis regarding students' school satisfaction, total time orientations during classroom disengagement, and perceived control. According to the results, all correlations between the variables were statistically significant. Among them, there is a positive correlation between School Satisfaction and Perceived Control $(\mathrm{r}=0.373, \mathrm{p}<.001)$. The correlation between school satisfaction and Total Time Orientation During Classroom Disengagement $(\mathrm{r}=.-284 ; \mathrm{p}<.001)$ and Total Time Orientation in During Classroom Disengagement and Perceived Control were negative $(r=.-126 ; p<.001)$.

Table 5. Multiple Regression Analysis Results Regarding School Satisfaction's Prediction of Total Time Orientation during Classroom Disengagement and Perceived Control

\begin{tabular}{|c|c|c|c|c|c|}
\hline Independent Variables & $\beta$ & Standard Error & Beta & $\mathrm{t}$ & $\mathrm{p}$ \\
\hline Constant & 19.576 & 1.777 & & 11.016 & $.00 *$ \\
\hline Total Time & -.063 & .015 & -.240 & -4.205 & $.00 *$ \\
\hline Perceived Control & .564 & .094 & .343 & 5.997 & $.00 *$ \\
\hline
\end{tabular}

Regression coefficient obtained at the end of the analysis was found to be significant $(\mathrm{R}=0.44 ; \mathrm{R} 2=0.19$; $\mathrm{F}=30.480 ; \mathrm{p}<.001$ According to the results, total time orientation $(\beta=.-24 ; \mathrm{p}<.001)$, which is the first variable examined in the effect of school satisfaction in regression equation, explains school satisfaction in a meaningful and negative way. the second variable, perceived control $(\beta=.34 ; \mathrm{p}<.001)$, was found to explain students' school 
satisfaction positively and significantly. It is seen after the regression analysis that Total Time Orientation $(\beta=$. 24; $\mathrm{p}<.001)$ explained students' school satisfaction in a statistically significant and negative way. On the other hand, Perceived Control $(\beta=.34 ; \mathrm{p}<.001)$ was found to explain student's school satisfaction in positive direction significantly.

\section{Discussion and Conclusion}

The results of this study revealed significant and important relationships between perceived control and school satisfaction. In addition, it was found that there is a negative relationship between time orientations during classroom disengagement and school satisfaction. It was seen that there is no significant relationship between demographic variables and school satisfaction.

There are studies on the effects of the relationship between school satisfaction and perceived control on teachers (Klassen and Chiu, 2010), high school students (Vieno, Santinello, Pastore and Perkins, 2007) and nurses (Han, 2013) in the relevant literature. The results of these studies showed that an increase in perceived control resulted in an increase in job satisfaction and school satisfaction. It is seen that the number of studies on primary school students regarding the issue is very low. This study revealed similar findings with these existing few studies conducted on different groups. This may be because perceived control is an important and strong positive psychological structure (Skinner, 1996). In addition, the high level of perceived control has been reported to have many positive consequences (Skinner, 1995). The fact that one of these positive results is to increase school satisfaction was put forward.

The results of the study indicated that there is a negative relationship was between time orientations during classroom disengagement and school satisfaction, which is an important indicator of students' participation in the course. There are many studies supporting the findings of this study (Ainley, 1991; Huebner and McCullough, 2000). Especially, the lack of satisfaction of students' needs is seen as one of the important reasons for not attending the course from the point of view of self-determination theory. In this sense, time orientations of elementary school children during classroom disengagement can also be seen as an experience in which studen ts demonstrate their existence as a defense. In other words, it can be thought that the students try to realize their self-determinations in a fantastic and negative way with the time orientations during classroom disengagement.

In this study, no significant relationship was found between school satisfaction and grade level and gender. This may be due to the fact that school satisfaction is an individual trait. Further studies are needed in the future.

Suggestions

Some suggestions can be put forth based on the results of this study. First, the perceived control levels of the students should be increased. At this point, teachers can improve students' perceived control by encouraging students to successful action, establishing the right cause-effect relationship, and demonstrating successful action (Skinner, 1995, 1996). Thus, students can express themselves positively in the classroom. As a result of this situation, the students move away from the time orientation during classroom disengagement.

\section{References}

Ainley, J. (1991). High school factors that influence students to remain in school. Journal of Educational Research, 85, 69-

80.

Baker, J. A. \& Maupin, A. (2009). School satisfaction and children's positive school adjustment. Handbook of Positive Psychology İn The Schools, 189-196.

Barton, P. E. (2004). One-third of a nation: Rising dropout rates and declining opportunities. Princeton, NJ: Policy Information Center, Educational Testing Service.

Casas, F., Bello, A., González, M. \& Aligué, M. (2013). Children's subjective well-being measured using a composite index: What impacts Spanish first-year secondary education students' subjective well-being? Child Indicators Research, 6 (3), 1-28.

Dereli-İman, E. \& Eryılmaz, A. (2012). Development of a scale for domain general perceived control scale primary school children's. TAF Preventive Medicine Bulletin, 11 (3), 331-338.

Diener, E. \& Diener, C. (1996). Most people are happy. Psychological Science, 7 (3), 181-185. 
Eryllmaz, A. \& Dereli, E. (2011). Psychometric properties of time orientation during classroom disengagement scale. Elementary Education Online, 10 (3), 1178-1190.

Ery1lmaz, A. \& Ercan, L. (2011). Initialing romantic intimacy at emerging adulthood: Is it Intimacy or Isolation. Journal of Gazi Education Faculty, 31, (2), 359-380.

Ery1lmaz, A. \& Ercan, L. (2011). Investigating of the subjective well-being based on gender, age and personality traits. Turkish Journal of Psychological Counseling and Guidance, 4 (36), 139-151.

Fredricks, J. A., Blumenfeld, P. C. \& Paris, A. H. (2004). School engagement: Potential of the concepts, state of the evidence. Review of Educational Research, 74, 59-109.

Han, S. J. (2013). The influence of academic self-efficacy and major satisfaction on career attitude maturity in nursing students. Korean Journal of Adult Nursing, 25 (5), 559-566.

Haranin, E., Huebner, E. S., \& Suldo, S. M. (2007). Predictive and incremental validity of global and domain-based adolescent life satisfaction reports. Journal of Psychoeducational Assessment, 25 (2), 127-138.

Huebner, E. S., \& McCullough, G. (2000). Correlates of school satisfaction among adolescents. The Journal of Educational Research, 93 (5), 331-335.

Kaplanc1, B. (2018). Examining the sense of responsibility of the primary school students in terms of school satisfaction and school attachment. Master Thesis, Sakarya University, Institute of Education Science.

Karasar, N. (2000). Scientific research method. Ankara: Nobel Publication.

Karatzias, A., Power, K. G., Flemming, J., Lennan, F. \& Swanson, V. (2002) The role of demographics, personality variables and school stress on predicting school satisfaction/ dissatisfaction: Review of the literature and research findings, Educational Psychology, 22 (1), 33-50.

Katja, R. Astedt-Kurki, P. \& Marja Terttu, T. (2009). Relationships Among adolescent subjective well - being, health behavior, and school satisfaction. Journal of School Health 72 (6), 243-249.

King, A. L. D., Huebner, S., Suldo, S. M., \& Valois, R. F. (2006). An ecological view of school satisfaction in adolescence: Linkages between social support and behavior problems. Applied Research in Quality of Life, 1 (3-4), 279-295

Klassen, R. M. \& Chiu, M. M. (2010). Effects on teachers' self-efficacy and job satisfaction: Teacher gender, years of experience, and job stress. Journal of educational Psychology, 102 (3), 741-756.

Lefcourt, H. M. (1982). Locus of Control: Current Trends in Theory and Research. New York: Plenum.

Martin, A. J. (2001) The Student Motivation Scale: A tool for measuring and enhancing motivation. Australian Journal of Guidance and Counselling, 11, 1-20.

Martin, A. J. (2002) Motivation and academic resilience: Developing a model of student enhancement. Australian Journal of Education, 47, 88-106.

Martin, A. J. (2003) How to motivate your child for school and beyond. Sydney: Bantam.

Morris, M. \& Pullen, C. (2007). Disengagement and re-engagement of young people in learning and key stage. England: Research and Practice.

Okun, M. A., Braver, M. W. \& Weir, R. M. (1990). Grade level differences in school satisfaction. Social Indicators Research, 22, 419-427.

Öksüz, Y., Güven Demir, E. \& Baba Öztürk, M. (2018). Examining the school satisfaction levels of Romani children with respect to some variables (Case of Samsun Province). H. U. Journal of Education, 33 (1), 256-268

Peterson, C., Maier, S. F. \& Seligman, M. E. P. (1993). Learned helplessness: A theory for the age of personal control. New York, NY: Oxford University Press.

Skinner, E. A. (1995). Perceived control, motivation, \& coping. London: Sage Publications. 
Skinner, E. A. (1996). A guide to constructs of control. Journal of Personality and Social Pscyhology, 71, 549-570

Yaşın, F. \& Büyükşahin-Sunal, A. (2016). Mediator role of relationship satisfaction in the relationship between time orientation and reactions to relationship problems. Turkish Journal of Psychology, 31 (78), 79-90.

Telef, B. B. (2014). Turkish adaptation study of overall school satisfaction scale for children. Journal of Theory and Practice in Education, 10 (2), 478-490.

Vieno, A., Santinello, M., Pastore, M. \& Perkins, D. D. (2007). Social support, sense of community in school, and self efficacy as resources during early adolescence: an integrative model. American Journal of Community Psychology, 39 (1-2), 177190.

Zimbardo, P. G. \& Boyd, J. N. (2008). The time paradox: The new psychology of time will change your life. New York: Free Press.

Zimbardo, P.G. \& Boyd, J.N. (1999). Putting time in perspective: A valid, reliable individual-differences metric. Journal of Personality and Social Psychology, 77, 1271-1288. 


\title{
ÇOCUKLARDA OKUL DOYUMU İLE DERSE
} KATILMAMA DURUMUNDAKI ZAMAN YÖNELIMI VE ALGILANAN KONTROL ARASINDAKI İLIŞKININ İNCELENMESI

\author{
Gülfem Meylan ŞAHİNBAŞ
}

Ali ERYILMAZ

Özkan SAPSAĞLAM

\begin{abstract}
Okul doyumu öğrencinin eğitim sürecinden ve okulda geçirdiği zamandan keyif almasıdır. Okul doyumunun yüksek olması öğrencinin akademik başarısını ve benlik imajını olumlu etkiler ve sosyal gelişimine katkıda bulunur. Bununla birlikte çocuğun akademik başarısını belirleyen başka unsurlar da bulunmaktadır. Derse katılım, dikkat, hatırlama ve algılanan kontrol gibi diğer bazı bireysel özellikler öğrenme çıktıları ve akademik başarı üzerinde etkili olmaktadır. Bu araştırma özel ve resmi bir ilkokulda 3. ve 4. sınıf düzeyinde öğrenim gören 253 öğrenci ile yürütülmüștür. Veri toplama araçları olarak, öğrencilerin demografik bilgilerinin yer aldığı Kişisel Bilgi Formu, Okul Doyumu Ölçeği, İlköğretim Çocukları İçin Derse Katılmama Durumundaki Zaman Yönelimi Ölçeği ve yine İlköğretim Çocukları İçin Genel Algılanan Kontrol Ölçeği kullanılmıştır. Nicel araştırma yaklaşımı ve ilişkisel tarama deseni üzerine kurgulanan araştırmada, nicel veri analiz yöntemleri kullanılmıştır. Veri analiz sürecinde $t$ testi ve çoklu regresyon analizinden yararlanılmıştır. Öğrencilerin, okul doyumu açısından cinsiyete ve sınıf düzeyine dayalı bir fark bulunmamıştır. Okul doyumuna etkisi incelenen ilk değişken olan derse katılmama durumundaki toplam zaman yöneliminin öğrencilerin okul doyumlarını anlamlı ve negatif yönde açıkladığı görülmüştür.
\end{abstract}

Anahtar Sözcükler: Algılanan kontrol, okul doyumu, derse katılmama, zaman yönelimi 